\title{
Piotr Kroczek
}

\section{Prawodawca i jego sztuka}

Prawo Kanoniczne : kwartalnik prawno-historyczny 50/1-2, 167-184

2007

Artykuł został zdigitalizowany i opracowany do udostępnienia w internecie przez Muzeum Historii Polski w ramach prac podejmowanych na rzecz zapewnienia otwartego, powszechnego i trwałego dostępu do polskiego dorobku naukowego i kulturalnego. Artykuł jest umieszczony w kolekcji cyfrowej bazhum.muzhp.pl, gromadzącej zawartość polskich czasopism humanistycznych i społecznych.

Tekst jest udostępniony do wykorzystania w ramach dozwolonego użytku. 


\section{KS. PIOTR KROCZEK}

Papieska Akademia Teologiczna w Krakowie

\section{PRAWODAWCA I JEGO SZTUKA}

Treść: Wstęp. 1. Tworzenie prawa. 2. Zasady postępowania prawodawcy. Wnioski.

\section{Wstęp}

W niniejszym artykule zostanie podjęta próba ukazania prawodawcy kościelnego i jego pracy oraz podanych zostanie kilka zasad, którymi prawodawca powinien się kierować.

W prawoznawstwie polskim można zauważyć postulat, aby redaktorzy tekstów prawnych nie formutowali tekstów prawnych wbrew poszczególnym od dawna przyjętym regulom ich odczytywania ${ }^{1}$. Jest bowiem tak, że to reguly redagowania wzorują się na regułach interpretowania ${ }^{2}$. Podobnie sprawę widzą kanoniści. W systemie prawnym Kościota prawodawca i interpretator nie tylko pracuja wspólnie, aby „lex canonica” pozostawata zawsze w stuzbie urzeczywistniania „communio Ecclesiae”, która zawsze jest zwiąana z dobrem osoby „Christifidelis”, ale co więcej, sam prawodawca jest pierwszym interpretatorem prawa ${ }^{3}$. Istnieje więc ścisła relacja pomiędzy tworzeniem przepisów a ich interpretacją. Skoro tak, to można korzystając z zasad interpretatora podanych przez J. A. Coridena ${ }^{4}$, napisać mutatis mutandis zasady prawodawcy.

Artykuł będzie się składał z dwóch zasadniczych części. W pierwszej przedstawiona zostanie teoria związaną $\mathrm{z}$ prawodawstwem, a w drugiej wspomniane zasady.

\footnotetext{
' M. Zi i li ń s k i, Wyktadnia prawa. Zasady. Reguly. Wskazówki, Warszawa 2002, s. 59.

${ }^{2}$ S. Wronk owsk a, Z. Zi e mbińsk i, Zarys teorii prawa, Poznań 1997, s. 134.

${ }^{3}$ L. Ge rosa, Interpretacja prawa w Kościele. Zasady, wzorce, perspektywy, przeł. K. Kubiś, A. Porębski, Kraków 2003, s. 151.

${ }^{4} \mathrm{~J}$. A. Cor i d e n, Rules for Interpreters, [w:] The Art of Interpretation. Selected Studies on the Interpretation of Canon Law, Washington 1982, s. 1-27.
} 


\section{Tworzenie prawa}

$\mathrm{Na}$ początku rozważań dotyczących tworzenia prawa należy udzielić odpowiedzi na trzy pytania': Pierwsze brzmi: Kto tworzy prawo w Kościele? Drugie dotyczy tego, Co tworzy prawodawca?, a trzecie podejmuje zagadnienie przebiegu tworzenia prawa i brzmieć może: Jak prawodawca tworzy prawo?

Odpowiedź na pierwsze pytanie wyznacza krąg znaczeniowy pojęcia prawodawca kościelny. Prawodawca kościelny (ustawodawca kościelny) to osoba lub zespół osób upoważnionych (kompetentnych, właściwych) do wydawania ustaw, czyli tworzenia prawa ${ }^{6}$. Prawodawca jest wlaściwy ze względu na osoby, którym prawa nadaje, ze względu na rzecz, którą nakazuje lub zakazuje, a także ze względu na terytorium, dla którego wydaje ustawę?.

Najważniejszym prawodawcą dla Kościoła jest Bóg, poprzez prawo naturalne i prawo Boże pozytywne. Ponadto do prawodawców mających zwyczajną władzę ustawodawczą w Kościele powszechnym zalicza się:

1. Biskupa rzymskiego, który posiada najwyższą, pełną, bezpośrednią i powszechną władzę w Kościele. Może on wydawać nowe ustawy, zmieniać istniejące lub znosić dawne. Granice jego prawotwórczej działalności wyznacza prawo naturalne i prawo Boże pozytywne (kan. 331, $333 \$ 1$ ).

2. Kolegium biskupów, razem $\mathrm{z}$ biskupem rzymskim, jako głową, a nigdy bez niej (kan. 336).

3. Na mocy władzy delegowanej może oglaszać ustawy także synod biskupów (kan. 343).

4. Zaś na mocy specjalnego papieskiego mandatu kongregacje rzymskie ${ }^{8}$.

Gdy zaś chodzi o prawodawców partykularnych ustaw Kościelnych zalicza się do nich:

\footnotetext{
${ }^{5}$ Por. R. S a rk ow ic z, J. St e l m a c h, Teoria prawa, Kraków 1996, s. 107 n.

- Trzeba pamiętać, o tym, iż spoleczność może sama się regulować i tworzyć sama dla siebie prawidła postępowania, które są zawarte w zwyczajach.

'F. B ą cz k ow i cz, Prawo Kościelne. Podręcznik dla duchowieństwa, t. I, przygotowal do druku i uzupelnit J. Baron i W. Stawinoga, Opole 1957, s. 190.

${ }^{8} \mathrm{~J}$ a n Pawel II, Constitutio Apostolica Pastor Bonus, 28 VI 1988, AAS 80 (1988), s. 841-912, nr 18.
} 
1. Konferencje biskupów w przypadkach określonych prawem powszechnym lub szczególnym postanowieniem Stolicy Apostolskiej (kan. 455 \& 1).

2. Synody partykularne (plenarne, prowincjalne) dla podległych sobie terytoriów (kan. 439-446).

3. Biskupów diecezjalnych, działających na synodach diecezjalnych lub poza nimi (kan. $381 \S 1$, kan. 466).

4. Wszystkich zrównanych z biskupami diecezjalnymi w prawie, czyli stojących na czele: prałatury terytorialnej i opactwa terytorialnego, wikariatu apostolskiego i prefektury apostolskiej, jak równiez administratury apostolskiej erygowanej na stałe (kan. $381 \S 2$, kan. 368).

5. Wyższych przełożonych i kapituły generalne kleryckich instytutów zakonnych i kleryckich stowarzyszeń życia apostolskiego na prawie papieskim, zgodnie $\mathrm{z}$ własnymi konstytucjami (kan. 134 § 1 , kan. $586 \S 1$, kan. 593, kan. $596 \S 1$ ).

Do prawodawców statutowych, czyli takich, którzy mogą wydawać prawo regulujące życie wewnętrzne określonych społeczności zaliczyć można:

1. Kapituły (katedralne i kolegiackie),

2. Zgromadzenia zakonne,

3. Stowarzyszenia religijne,

4. Wyższe uczelnie.

Wydane przez nie statuty nabierają mocy obowiązującej po zatwierdzeniu ich przez kompetentnego przełożonego. Zatwierdzenie takie nie zmienia charakteru przepisów, czyli pozostają one ustawą społeczności, osoby prawnej, a nie zatwierdzającego przełożonego".

Warto przypomnieć w tym miejscu, że KPK nie przyznaje żadnym podmiotom, poza obdarzonymi władzą ustawodawczą, prawa do inicjatywy ustawodawczej, co zadaniem R. Sobańskiego nie ogranicza prawa wiernych wypływającego z kan. $212 \S 2$ do przedkładania sugestii czy projektów. Takie działania mogą być też podjęte przez gremia doradcze: synod biskupów, kolegium kardynałów, synod diecezjalny, radę kaplańską, kolegium konsultorów wyłonione $z$ rady kapłańskiej, kapitułę kanoników, diecezjalną ra-

\footnotetext{
${ }^{9}$ R. S o b a ń s k i, Normy ogólne Kodeksu Prawa Kanonicznego, W'arszawa 1969, s. 43.
} 
dę duszpasterską ${ }^{10}$. Trzeba w tym miejscu pamiętać także o tym, że prawo zazwyczaj tworzone jest „od góry” czyli przez akt prawodawcy, ale także „od dołu” poprzez zadawnienie zwyczaju (zob. kan. 23-38).

Piśmiennictwo rozróżnia pojęcie prawodawcy w ujęciu dogmatycznym oraz socjologicznym (faktycznym) ${ }^{11}$. Prawodawca w ujęciu dogmatycznym to podmiot, któremu konwencjonalnie przypisuje się wytwór działalności prawotwórczej. Jest on wyposażony w kompetencje do wykonywania czynności konwencjonalnych, jakimi są akty stanowienia przepisów prawnych. Zaś prawodawcą w ujęciu socjologicznym jest ten podmiot lub te podmioty, które biorą udział w procesie przygotowania tekstu prawnego i wywierają rzeczywisty wpływ na ustalenie określonych treści. Podane przez nas zasady będą dotyczyły głównie, ale nie wyłącznie, prawodawcy w ujęciu socjologicznym.

Odpowiadając na drugie pytanie postawione na początku tej części artykułu, a mianowicie: Co tworzy prawodawca? trzeba dokonać ważnego rozróżnienia. Tworzenie prawa może być rozumiane na trzy sposoby'2:

1. Tworzenie porządku prawnego, rozumianego jako wyznaczony przez obowiązujace normy prawne uklad organów $i$ instytucji oraz procedur rozstrzygania określonych spraw, a także wyznaczone przez owe normy zachowania podmiotów prawa, rozważane w powiazaniu $z$ zachowaniami innych osób $i$ instytucji $i^{13}$.

2. Tworzenie systemu prawnego, który jako trzon porządku prawnego rozumiany jest najczęściej jako uporządkowany zbiór norm prawnych.

3. Tworzenie aktów prawnych, czyli redakcja poszczególnych zbiorów przepisów prawnych.

Przy podejściu interdyscyplinarnym, lączącym prawo z socjologią czy politologia przydatne jest rozumienie tworzenia prawa jako tworzenia porządku prawnego, który jest elementem calego porządku

\footnotetext{
${ }^{10}$ J. Kr u kowski, R. Sobańsk i, Komentarz do Kodeksu Prawa Kanonicznego, t. 1, Ksiega l, Normy ogólne, Poznań 2003, s. 56.

"M. Zie lińs ki, Wykladnia prawa.., s. 278.

"2 Por. R. Sarkowicz, J. St el m a ch. Teoria ..., s. 108-111.

${ }^{13} \mathrm{~A}$. Redelbach, S. Wr on kowska, Z. Zie mbiński, Zanys teorii państwa i prawa, Warszawa 1992, s. 232.
} 
społecznego. Gdy sięga się do filozofii prawa i stosuje metodologię takich dyscyplin jak: logika, językoznawstwo czy filozofia języka wówczas najbardziej adekwatne jest rozumienie tworzenia prawa, jako tworzenie systemu prawnego, czy ostatecznie systemu norm. Oczywiście przy założeniu, że prawodawca zakodowal normy w przepisach prawa, a odkrycie norm następuje w procesie interpretacji. Jeśli zaś góruje nastawienie praktyczne to tworzenie prawa będzie tylko techniką redakcyjną aktów prawnych. Zasady prawodawcy, jakie będą sformułowane w drugiej części artykułu dotyczyć będą zarówno porządku prawnego, jak i systemu prawnego, oraz samej techniki redakcji aktów prawnych.

W KPK zarówno z 1917 roku jak i 1983 roku brak jest definicji ustawy. Kanonistyka posługuje się definicją ustawy podaną przez św. Tomasza: rationis ordinatio ad bonum commune, ab eo qui curam communitatis habet, promulgata ${ }^{14}$. Zdaniem niektórych autorów nie jest ona adekwatna do ustawy kościelnej, gdyż wynika jedynie z filozoficznej analizy życia spolecznego, a nie bierze pod uwagę nadprzyrodzonych czynników uspolecznienia, które są poznawalne jedynie przez wiarę ${ }^{15}$. Lepiej więc zdefiniować ustawę kościelną wymieniając jej cechy uzyskane poprzez analizę kodeksu' ${ }^{16}$. Brzmią one: prawnie zobowiazujący charakter; rozumność; dzieto kompetentnego prawodawcy; zaadresowana do generalnie określonej grupy osób; ujęcie abstrakcyjne nieokreślonej liczby przypadków, stalość, promulgacja, innowacyjnośc ${ }^{17}$.

KPK nie wprowadza także podzialu ustaw kościelnych, ani terminologii w tym zakresie. Zazwyczaj doktryna dzieli ustawy na powszechne, czyli dotyczące całego Kościoła i partykularne, które obowiązują w części Kościola. Ustawy mogą być personalne i tery-

${ }^{14}$ Św. Tomasz, Suma teologiczna, I-II, q. 90, a. 4 co. (Wersja oryginalna oparta na wydaniu: S. Thomae Aquinatis, Opera omnia iussu impensaque Leonis XIII P. M. edita, $t$. 6-7: Prima secundae Summae theologiae, Ex Typographia Polyglotta S. C. de Propaganda Fide, Romae, 1891-1892) dostępna pod adresem: http:/(www.corpusthomisticum.org). Analiza tej definicji zob.: R. So bańs k i, Normy ogólne..., s. 38 n.

is Zob. np. R. Sobań sk i, Ustawa kościelna - ordinatio rationis czy ordinatio fidei?, Collectanea Theologica 48 (1978) f. 1, s. 27-35.

${ }^{16} \mathrm{O}$ takim sposobie tworzenia definicji zob. T. Ko ta r biński. Elementy teorii poznania, logiki formalnej $i$ metodologii nauk, [w:] Dziela wszystkie, t. 1, Wroclaw/Kraków/Gdańsk/Lodź 1990, s. 52 nn.

${ }^{17}$ R. So bańs k i, Nauki podstawowe prawa kanonicznego, t. 1, Teoria prawa kanonicznego, Warszawa 2001, s. 52, czy np.: J. Kru k ow sk i, R. Sob ańs ki, Komentarz..., s. 55. 
torialne, w zależności od tego czy wiążą osobę bezpośrednio, czy poprzez terytorium, na którym osoba się znajduje. Inny podział ze względu na autora ustawy: papieskie, biskupie, synodalne, itd. $\mathrm{Z}$ uwagi na przedmiot i skutek ustawy podzielić można na nakazujace, zakazujace, dopuszczajace, uniezdalniajace, unieważniajace i karne ${ }^{18}$.

Ważne jest, aby idąc za powszechną opinią istniejącą w prawoznawstwie świeckim ${ }^{19}$, rozróżnić ustawę, przepis i normę. Ustawa według definicji R. Sobańskiego to akt normatywny wydany w celu wprowadzenia $w$ życie (Kościola) norm prawnych (czyli kanonicznych). Ustawa to tekst, który sktada się ze zdañ ${ }^{20}$. Zaś przepisem można określić zdanie budujące ustawę wyraźnie wyróżnione graficznie w tekście prawnym i stosownie oznaczone jako np. artykuł czy ustęp $\mathrm{p}^{21}$. KPK używa synonimicznie tych nazw.

Odpowiadając na trzecie pytanie, mianowicie Jak prawodawca tworzy prawo? należy idąc na niektórymi autorami odróżnić formy tego procesu, a mianowicie proces ksztaltowania się prawa od procesu jego tworzenia ${ }^{22}$.

Proces ksztaltowania sie prawa to pewne wydarzenia społeczne, które prowadzą do wytworzenia się systemu prawodawstwa lub zmiany w nim. Chodzi tu więc o pewne mechanizmy biorące udzial w powstawaniu prawa. Działalność poszczególnych osób lub ich zespołów, które świadomie dążą do osiągnięcia pewnych celów przy pomocy prawa.

\footnotetext{
${ }^{18}$ T. P aw lu k, Prawo Kanoniczne wedlug Kodeksu Jana Pawła II, t. I, Olsztyn 1985, s. 216.

${ }^{19}$ Jako pierwszy rozróżnienia pomiędzy norma a przepisem prawnym wedle kryterium pojęciowego dokonał Z. Zi e m bińs k i, Przepis prawny a norma prawna, Ruch Prawniczy i Ekonomiczny (1960), nr 1, s. 105-122. W cieszącej się obecnie największym autorytetem wśród prawników koncepcji wykladni prawa derywacyjnej autorstwa Z. Zi e m b ińs k ie go, Logiczne podstawy prawoznawstwa, Warszawa 1966, a rozwiniętej przez M. Zi eliń s k i g o, Interpretacja jako proces dekodowania tekstu prawnego, Poznań 1972 to rozróżnienie jest fundamentalne. Głównym rysem tej koncepcji jest to, że zadaniem wykładni prawa jest odtworzenie $\mathrm{z}$ przepisów prawnych norm postępowania wraz z ich percepcją. Warto zauważý, że w nieco zapomnianej koncepcji semantyczno intensjonalnej (klaryfikacyjnej) interpretacji tekstu prawnego autorstwa J. Wróblewskiego przedstawionej w pracy Zagadnienia teorii wyktadni prawa ludowego, Warszawa 1959 oraz innym dziele: W. La ng, J. Wróblewski, S. Zawa dzk i, Teoria państwa i prawa, Warszawa 1980, nie przywiązuje się wagi do różnicy pomiędzy przepisem prawnym a normą prawna.

${ }^{20}$ R. Sobańs ki, Nauki podstawowe..., s. 52.

${ }^{21}$ M. Zie lińsk i, Wykladnia prawa..., s. 16.

${ }^{22}$ Por. A. Mich halsk a, S. Wr on kowsk a, Zasady tworzenia prawa, Poznań 1983, s. 18-19 , czy też: S. Wron kows k a, Z. Zi e m bińs k i, Zanys teorii prawa, Poznań 1997, s. 128.
} 
W KPK z 1983 r. w Tytule I Ustawy Koscielne nie ma podanych (z wyjątkiem, kan. 7 i 8 ) przepisów dotyczących procedur legislacyjnych. Tworzenie prawa wedlug prawoznawstwa następuje zwykle w wyniku stanowienia, umowy, uznania, precedensu prawotwórczego ${ }^{23}$. Dla dalszych rozważań istotne będą trzy pierwsze $\mathrm{z}$ wymienionych form: stanowienie, umowa $i$ uznanie, trudno bowiem wskazać sytuację w Kościele, w której prawo tworzone jest poprzez precedens prawotwórczy, czyli wypracowywanie powszechnej normy przy okazji rozstrzygania konkretnej sprawy. Oczywiście orzeczenia Roty Rzymskiej i Sygnatury Apostolskiej czyli stylus curiae Romanae mają znaczenie dla rozstrzygania spraw w sądach niższej instancji, ale te wyroki sądowe i administracyjne nie tworzą obowiązującego precedensu. Mają one swoją wartość, wywierają wpływ na inne sądy kościelne, które cytują jej decyzje, aby wzmocnić swoją argumentację.

Wypada dodać, że Trybunały Kościelne nie tylko aplikują prawo, lecz także przyczyniają się do jego rozwoju, jak to np. miało miejsce z kan. 1095 n. 3 (mówiącym o zdolności do podjęcia istotnych obowiązków małżeńskich z przyczyn natury psychicznej) ${ }^{24}$.

Najczęściej występująca forma tworzenia prawa, to stanowienie prawa, które zdefiniować można jako jednostronny akt prawotwórczy kompetentnego podmiotu w wyniku którego powstają normy generalne i abstrakcyjne. Do ważności tego aktu prawnego nie jest wymagana zgoda adresatów prawa, choć kanoniści odróżniają akceptację aprobującą, czyli akceptację w znaczeniu ścisłym (zgoda na ustawę) od akceptacji wykonawczej (przestrzeganie ustawy) ${ }^{25}$. To rozróżnienie będzie nam potrzebne w dalszych rozważaniach. Gdy chodzi o umowe, to występuje ona na gruncie Kościelnym głównie w prawie międzynarodowym, czyli np. w postaci konkordatów. Uznanie natomiast to wcielanie norm prawa zwyczajowego. Źródło mocy obowiązującej takiego prawa tkwi według niektórych w porozumieniu wiernych, według innych w zgodzie przełożonego. Przeważa jednak zdaniem $R$ : Sobańskiego ta druga tendencja, która zabezpiecza wplyw prawodawcy na powstanie prawa zwyczajowego ${ }^{26}$.

\footnotetext{
${ }^{23}$ Por. R. S a r k ow icz, J. S te l m a ch, Teoria prawa, Kraków 1996, s. 112-113.

${ }^{24}$ L. Ge ros a, Interpretacja..., s. 152.

${ }^{25}$ R. Sobańs ki, Nauki podstawowe..., s. 101.

${ }^{26}$ Tamże, s. 59-62.
} 
Stanowienie prawa, najbardziej nas interesujący sposób tworzenia prawa, ma zdaniem L. Örsego następujące etapy ${ }^{27}$ :

1. Koncepcja prawa, czyli zejście się trzech elementów wynikających z oceny sytuacji przez prawodawcę: - dostrzeganie przez prawodawcę wartości obiektywnie dobrych, jakie można by uzyskać, - odkrycie egzystencjalnych potrzeb wspólnoty, - pytanie skierowane do wspólnoty czy jest zdolna sięgnać po te wartości i je przyswoić. Wszystkie te trzy elementy zbiegają się w jedną normę: Wspólnota powinna zrobić to, a to. Ten etap można za R. Sobańskim nazywać inicjatywa ustawodawczą.

2. Projekt prawa, czyli ujęcie myśli prawodawcy w konkretne prawne sformułowania, zaczerpnięte $z$ tradycji prawniczej. Nowe normy prawne powinny być zgodne $\mathrm{z}$ już istniejącymi. W tym punkcie mieści się ustalenie treści i sporządzenie tekstu ustawy.

3. Promulgacja prawa, czyli zaistnienie tekstu prawnego (jak to mówi kan. 7: Ustawa powstaje z chwila jej promulgowania), ale nie jeszcze jego obowiązywanie. Zasady promulgacji są określone np. w kan. 8. Ustawa przez promulgację staje się „faktem publicznym”. Promulgacja nie jest równoznaczna $z$ rozpowszechnieniem czy faktycznym zaznajomieniem się $z$ ustawą ${ }^{29}$.

4. Vacatio legis, czyli czas w którym ustawa jest zawieszona. Jest to czas dany wspólnocie, na to, aby zaznajomiła się z nowym prawem. Czas vacatio legis jest określony albo przez prawodawcę, albo przez samo prawo które zostało promulgowane. Nie doznają zawieszenia ustawy, które wiążą z chwilą ogłoszenia, czyli te, które zawierają prawo Boże, mają formę ustaw konkretyzujących ustawy już obowiąujące, interpretacje autentyczne dokonane w formie ustawy i ogłoszone, a wyjaśniające stowa same w sobie pewne (kan. $16 \S 2)^{30}$.

5. Petne życie prawa, przez które wiąże ono wspólnotę. Na tym kończy się główne zadanie prawodawcy. Oczywiście w Kościele, inaczej niż w prawie świeckim, prawodawca ma obowiązek interesować się losami ustawy i poprzez wykładnię autentyczną (kan. 16) dokonywać korekty jej zapisu czy rozumienia ${ }^{31}$. Interpretacja autentyczna

${ }^{27}$ L. Örsy, The interpreter and his art, The Jurist 40 (1980), s. 29-30.

${ }^{28}$ J. Kruk owski, R. Sobańsk i, Komentarz..., s. 55.

${ }^{29}$ Tamże, s. 56.

${ }^{30}$ Tamże, s. 58.

${ }^{31}$ Zbiór interpretacji autentycznych dokonanych przez Papieską Radę Interpretacji Ustaw wraz z komentarzem można znaleźć w książce: L. G. Wr en n, Authentic Interpretation on the 1983 Code, Washington 1993. 
dokonana per modum legis, gdy jest formalnie promulgowana, równa się powadze samej ustawy, uzupełnia ją i stanowi jej integralną część.

Można by uzupelnić te punkty o jeszcze jeden a mianowicie: uchwalenie ustawy, gdy prawodawca jest kolegialny. Ten punkt mieściłby się pomiędzy projektem a uchwaleniem $^{32}$.

\section{Zasady postępowania prawodawcy}

Zasady postępowania prawodawcy pogrupowane zostaną w trzy grupy zasad odnoszące się do: (1) osoby prawodawcy, (2) wspólnoty, dla której prawo jest stanowione, (3) stanowionego prawa.

W pierwszej grupie zasad odnoszących się do osoby prawodawcy czołowa zasada brzmi: Poznaj siebie. Każdy akt ludzki ma w sobie coś z człowieka, który go dokonuje. Nie inaczej jest w prawie. Ważną rolę odgrywają tu takie czynniki jak: kultura, której prawodawca jest uczestnikiem, społeczeństwo którego jest członkiem, jego świat wartości, preferencji, a nawet życie psychiczne prawodawcy. Prawodawca musi zdawać sobie sprawę ze swoich ludzkich ograniczeń. Możliwie pełna i obiektywna prawda o sobie samym jest dobrym punktem wyjścia do pracy prawodawczej.

Następna zasada brzmi: Pamiętaj o swoim horyzoncie teologicznym i filozoficznym. B. Gangoiti pisze, że to jaki jest kodeks (a można powiedzieć, że generalnie cale prawo kościelne) zależy od tego jaka jest filozofia i teologia. Jego zdaniem te dwa czynniki filozoficzny i teologiczny bardzo mocno kształtują podstawy prawa ${ }^{33}$. Choć prawodawca nie wywodzi prawa bezpośrednio $\mathrm{z}$ danych $\mathrm{Ob}-$ jawienia, to jest on pod wplywem doktrynalnych wizji i teologicznych opinii. W ten sposób przechodzą one do prawa czasami wyraźnie, czasami niewyraźnie. Oczywiście więcej będzie teologii w prawach dotyczących sakramentów niż np. w ustawach dotyczących dóbr doczesnych.

Kolejna, trzecia zasada ma brzmienie: Bądź roztropny. Roztropność to cnota pokazująca człowiekowi właściwą drogę do osiągnięcia celu ${ }^{34}$. Św. Tomasz cnotę, która uzdalnia do rządzenia innymi w sposób mądry i słuszny uważa za najbardziej specjalna $i$ pet-

${ }^{32}$ Tak np. J. K r u kowski, R. Sobański, Komentarz..., s. 55.

${ }^{33}$ B. Gangoit i, Teologia e Filozofia del Diritto del Nuovo Codice, Angelicum 60 (1983), s. 517-518.

${ }^{34}$ Sw. Tomasz z Akwinu, Suma teologiczna, II-II, q. 47, a. 2 co. 
$n q^{35}$ i nazywa ją roztropnością rządzenia (prudentia regnativa) ${ }^{36}$. Jest ona właściwa dla przywódców. Każdy akt roztropny ma trzy etapy ${ }^{37}$. Pierwszy to namysł zaradczy, czyli poszukiwanie rozwiązania, drugi to osądzanie tego, co zostało znalezione i trzeci to nakaz zastosowania tego co zostało znalezione i osądzone.

Roztropność może uchronić przed idealizmem administracyjnym, który polega na naiwnym przekonaniu, iż samo ustanowienie prawa zmieni rzeczywistość $\mathrm{w}$ pożądanym kierunku. Po rozważeniu sprawy można dojść do wniosku, że stanowienie prawa nie jest najlepszym środkiem oddziaływania, i że zaniechanie tworzenia prawa będzie decyzją racjonalną̧ ${ }^{38}$. Musi więc prawodawca mieć przed oczami cel swojego działania, czyli dobro jakie chce osiągnąć. Służyć to ma doborowi właściwych środków.

Zdobądź odpowiedniq wiedzę to zasada piąta. Podejmowanie decyzji w procesie prawotwórczym musi zawsze odbywać się w oparciu zarówno o określoną wiedzę prawniczą jak i z zakresu rzeczywistości, która ma podlegać regulacji prawnej. Postulat wiedzy prawodawcy i ocen jakich na jej podstawie dokonuje jest podstawowy dla założenia prawodawcy racjonalnego ${ }^{39}$. Postulaty wysuwane wobec prawodawcy są tu następujące:

1. Wiedza prawodawcy ma być niesprzeczna.

2. Wiedza prawodawcy ma być systemem, który uwzględnia konsekwencje logiczne.

3. Prawodawca ma określone preferencje, które są asymetryczne (jeśli preferuje A przed B to nigdy nie preferuje B przed A).

4. Prawodawca ma określone preferencje, które są przechodnie (jeśli A preferuje przed $\mathrm{B}$ i przed $\mathrm{C}$, to $\mathrm{B}$ preferuje przed $\mathrm{C}$ i to A preferuje przed $\mathrm{C})^{40}$.

Dokonaj catościowej oceny skutków rozwiazania prawnego proponowanego $i$ innych rozwiazań konkurencyjnych ${ }^{41}$, to kolejna szósta

\footnotetext{
${ }^{35}$ Tamże, II-II, q. 50 a. 1 co.

${ }^{36}$ Tamże, II-II, q. 50, a. 2 , ad 1.

${ }^{37}$ Tamże. II-II, q. 47, a. 8 co.

${ }^{38} \mathrm{~S}$. Wronk ows k a, Z. Zie mbiński, Zarys.., s. 134-135.

${ }^{39}$ L. Nowak, Interpretacja prawnicza. Studium z metodologii prawoznawstwa, Warszawa 1973 , s. 39.

${ }^{40}$ M. Zielińsk i, Wykladnia prawa..., s. 279.

${ }^{41}$ Koresponduje to $z$ koncepcja nauki o prawodawstwie, określanej jako „polityka prawa”. Jej autorem jest L. Pe tr a ż y cki. Pisze on: „Istota zagadnień polityki prawa po-
} 
zasada, która polega na sformułowaniu oceny zamierzonego rozwiązania prawnego i innych konkurencyjnych (jeśli takie są) z różnych punktów widzenia oraz $\mathrm{z}$ uwzględnieniem różnych aspektów określonego stanu rzeczy, a więc na dokonaniu swoistej syntezy różno aspektowych ocen. Trzeba brać pod uwagę nie tylko ocenę określonego rozwiązania prawnego, ale także inne ogólne wartości, takie jak stabilność systemu prawa czy poczucie bezpieczeństwa prawnego, których naruszanie może istotnie obniżać prestiż, a w konsekwencji - gotowość posłuchu dla norm stanowionych w przyszłości ${ }^{42}$.

W drugiej grupie zebrane zostały zasady, jakimi powinien kierować się prawodawca mając w swojej optyce wspólnotę, dla której stanowi prawo.

Pierwsza zasada brzmi: Bierz pod uwagę wspólnotę, dla której jesteś prawodawca. Prawodawca musi w swoim zamyśle normy uwzględnić czy stanowi normę dla wspólnoty regionu, diecezji, wspólnoty klasztornej, itd. Ma wziąć pod uwagę nie tylko jej liczebność, ale i ich kondycję duchową, moralną. Nie bez znaczenia jest to, że ustawa kościelna jako taka wprowadza, oprócz zobowiązania prawnego wobec władzy kościelnej także obowiązek moralny, czyli, że wiąże poddanych w sumieniu i wobec Boga ${ }^{43}$. Prawodawca powinien też uwzględnić ważne czynniki takie jak kulturę lub kultury z jakich pochodzą ci, dla których stanowi prawo, sytuację polityczną, ekonomiczną w jakiej żyją, wykształcenie, normy przyjęte społecznie. Obowiązuje tu zasada, że im więcej czynników weźmie pod uwagę, czyli im lepsza będzie znajomość wspólnoty przez prawodawcę tym lepiej.

Druga zasada ma brzmienie: Przewiduj akceptację ustawy. Prawo stanowione przez kompetentną władzę, ze względu na jej charakter i funkcje, nie musi mieć akceptacji aprobującej dla swojej ważności czy obowiązywalności. Niewątpliwie akceptacja wykonawcza ma duże znaczenie, bowiem prawo nie przestrzegane jest martwe. Norma nie przestrzegana jest martwa. Ustawy od początku nie przyjęte

lega na uzasadnionym naukowo przewidywaniu nastepstw, jakich spodziewać się należy $w$ razie wprowadzenia pewnych przepisów prawnych oraz na opracowaniu zasad, których wprowadzenie do systemu prawa obowiqzujacego (...) wywolaloby pewne pożadane skutki,

L. Pe $t$ r aży ck i, Wstęp do nauki prawa i moralności, Warszawa 1959, s. 13.

${ }^{42} \mathrm{~S}$. Wronk owska, Z. Zie mbińsk i, Zarys..., s. 135-136.

${ }^{43}$ R. Sobań s k i, Nauki podstawowe..., s. 106. 
i nie przestrzegane, czy też od początku przyjęte, lecz potem odrzucone tracą moc prawną. Istnieje więc powiązanie wejścia w życie ustawy poprzez promulgację i wejście w życie wspólnoty przez jej przestrzeganie. Pisząc ustawy prawodawca musi uwzględniać to czy dane normy znajdą zrozumienie. L. Örsy definiuje przyjęcie prawa przez członków wspólnoty jako akt posłuszeństwa pochodzacy od inteligentnego $i$ wolnego sumienia ${ }^{44}$. Przykładem ustawy, która nie została przyjęta przez wspólnotę jest Constitutio Apostolica Jana XXIII Veterum Sapientia z dnia 22 II $1962^{45}$. Dokument ten promował nauczanie języka łacińskiego oraz zawierał pewne zalecania dotyczące prowadzenia wykładów w tym języku.

Prawodawca powinien więc działać, zgodnie $\mathrm{z}$ następną, trzecią już zasadą Zadbaj o akceptację i recepcję ustawy ${ }^{46}$. Aby uzyskać akceptację wykonawczą, prawodawca powinien wyjaśniać wspólnocie motywy, jakimi kierował się przy ustanawianiu ustaw ${ }^{47}$. Nie jest to oczywiście wymóg formalny, ale na pewno przyczynia się do tego, że ustawa będzie szerzej przyjęta, a normy w niej zawarte chętniej wypełniane. Musi on pamiętać, że stanowienie prawa to nie tylko proces odgórny ${ }^{48}$. Jak pisze R. Sobański: $Z$ punktu widzenia troski o jedność wspólnoty istotna jest nie tylko formalna ważność, lecz skuteczność ustawy ${ }^{49}$. Wyjaśnienie celu ustawy dokonuje się niekiedy w samym dokumencie ${ }^{\text {s0 }}$.

${ }^{44}$ L. Örsy, Theology and Canon Law: new Horizons for Legislation and Interpretation, Collegeville 1992 s. 124.

${ }_{45}$ J a n XXIII, Constitutio Apostolica Veterum Sapientia, 22 II 1962, AAS 54 (1962), s. 129-135; o tym zob.: L. Ge ros a, Prawo Kościola, przeł. I. Pę k als k i, Poznań 1999, s. 102, przypis 103; zob. także: L. Örsy, The Interpretation of Laws: New Variations on an Old Theme, [w:] The Art of Interpretation. Selected Studies on the Interpretation of Canon Law, Washington 1982, s. 70, przypis 23.

${ }^{46}$ Więcej o recepcji prawa we wspólnocie Kościola: R. Sobański, Recepcja prawa w Kościele, Prawo Kanoniczne 46 (2003), nr 3-4, s. 3-14; a szczególnie podana w przypisie 62 literatura; zob. także: L. Ö rsy, The Reception of Laws by the People of God: a Theological and Canonical Inquiry in the Light of Vatican Council II, The Jurist 55 (1995), s. 504-526.

${ }^{47}$ Zagadnienie akceptacji ustawy kościelnej podejmuje: R. Sobański, Kościót prawo-zbawienie, Katowice 1979, s. 194-197.

${ }^{48}$ R. Sob ań s ki, Recepcja prawa w Kościele, Prawo Kanoniczne 46 (2003), nr 3-4, s. 13.

${ }^{49} \mathrm{R}$. So b a ńs ki, Kościót jako podmiot prawa. Elementy eklezjologii prawnej, Warszawa 1983 , s. 172.

${ }^{50}$ Zob. np.: Papieska Rada Do Spraw Jedności Chrześcijan, Directoire pour l'application des principes et des normes sur l'oecuménisme, 25 III 1993, AAS 85 (1993), s. 10391119 , nr 6, gdzie wymienia się cele tego dokumentu. 
Czwarte zalecenie dla prawodawcy to: Wstuchuj się $w$ gtosy wspólnoty po wejściu ustawy $w$ życie. Chodzi tu o wspomnianą już w pierwszej części artykułu interpretację autentyczną. Wykładnia autentyczna ma w Kościele wielką wartość. Ustawa w prawie kanonicznym od momentu promulgacji „nie żyje własnym życiem”, bo praktyka, jaką ustanawia, to praktyka wiary ${ }^{51}$. Przelożony kościelny ma bowiem obowiązek ogłosiwszy ustawę, interesować się jej losem i w razie potrzeby skorygować jej zapis lub wyjaśnić wątpliwości interpretacyjne. Zaś autorytet, wynikający ze sprawowanej władzy, pozwala mu wymagać od wiernych posłuszeństwa swoim decyzjom także odnośnie stosowania i przestrzegania prawa.

Ostatni, trzeci zbiór zasad odnosi się do tekstu prawa.

W tym zbiorze pierwsza zasada brzmi: Pamietaj, po co jest prawo $w$ Kościele. Prawo kanoniczne jest w swej istocie zjawiskiem religijnym, które istnieje w Kościele. Celem prawa kanonicznego jest służba Kościołowi, którego bez wiary nie można pojąć, a jego prawo zawsze trzeba pisać w odniesieniu do tajemnicy zbawienia (por. Optatam totius 16). $\mathrm{Z}$ tej tajemnicy czerpie sens praktyka prawa w Kościele. Prawodawca w Kościele musi pamiętać, że choć prawo jest nośnikiem jego woli, to musi być ona i ograniczona i podporządkowana naczelnej zasadzie salus animarum suprema lex ${ }^{52}$ (por. kan. 1752). Ta perspektywa nigdy nie może być pominięta przy stanowieniu prawa. R. Sobański pisze: Prawo Kościola nie może być odseparowane od Kościola; ono należy do rzeczywistości Kościoła ${ }^{53}$.

Druga zasada to: Zadbaj o poprawność teologiczna prawa. Skoro prawo kanoniczne jest rzeczywistością eklezjalną jest też rzeczywistością teologiczną. Kościół przecież, to w pierwszym i zasadniczym rzędzie przedmiot teologii. Jest tak dlatego, że Kościót $w$ swojej istocie należy do tajemnic wiary i podlega rygorom poznania teologicznego $o^{54}$. Kanonista powinien być też teologiem, który rozumie, funkcję prawa w Kościele. Musi rozumieć naturę dogmatyczną instytucji Kościoła, aby je przekładać na język norm.

\footnotetext{
s1 R. Sobański, Uwagi o interpretacji prawa kościelnego, Prawo Kanoniczne 30 (1987), nr 1-2, s. 44.

${ }_{52}$ I wo z Chartres, Omnis institutio ecclesiasticarum legum ad salutem referenda sit animarum. Epistula 60. PL 162,74.

${ }^{53}$ R. Sobańs k i, Grundlagenproblematik des katholischen Kirchenrechts, Wien/Köln 1987, s. 141.

${ }^{54}$ R. S o b a ńsk i, Teoria prawa Kościelnego, Prawo Kanoniczne 31 (1988), nr 1-2, s. 5.
} 
W prawie kanonicznym przecież światy prawa i teologii stają się organiczna jednościa ${ }^{55}$

Idąc dalej w trzeciej zasadzie można postulować: Ustanawiaj prawo zgodnie z myśla Soboru Watykańskiego II. Skoro ideą soborowej zmiany bylo novus habitus mentis ${ }^{\text {sh }}$, także i prawo stanowione musi tę myśl odzwierciedlać. Teologia soborowa pojawia się w kodeksie. To oczywiste skoro kodeks to magnus nisus transferendi, który tę doktrynę soborową przenosi na język kanonistyczny ${ }^{57}$. Wiele kanonów jest bezpośrednio inspirowanych czy nawet bez zmian wziętych z dokumentów soborowych. Sumując więc można powiedzieć, że Sobór jest przewodnikiem dla prawodawcy.

Czwarta zasada ma brzmienie: Badź zorientowany w istniejacym systemie prawnym. Może to, co prawodawca chce napisać już zostało napisane, ale nie jest poznane przez członków wspólnoty, lub do przestrzegania określonych norm trzeba członków wspólnoty przynaglić. Prawodawca kościelny powinien uważać, aby nie przyczyniać się do kryzysu legislacyjnego, który polega przede wszystkim na nadmiernej liczbie wydawanych aktów prawnych oraz niestabilności prawa, spowodowanej częstymi korekturami przepisów i licznymi błędami decyzyjnymi prawodawcy ${ }^{58}$.

Prawodawca musi przestrzegać piątej zasady: Staraj sie formutować jasne prawo. W swojej pracy powinien szukać takich rozwiązań, które zaowocuja tekstem prawa jasnym możliwie dla wszystkich, których prawo ma dotyczyć. Chodzi tu o właściwy sposób zbudowania tekstu prawa, ale także o to, aby w swojej pracy brał pod uwagę adresata prawa, czyli m.in. potrzeby i oczekiwania adresata prawa w stosunku do prawa, możliwości percepcji prawa, wiedzę i poziom doświadczenia prawniczego.

Jasność prawa jest ujmowana na różne sposoby. K. Opałek i J. Wróblewski wyróżniają trzy rodzaje jasności prawa ujęte z punktu widzenia funkcji jasności prawa $\mathrm{w}$ dyskursie prawniczym ${ }^{59}$ :

\footnotetext{
${ }^{55}$ L. Ö rsy, Theology and Canon Law..., s. 170.

${ }^{56}$ Zob. L. Ö r sy, The meaning of "novus habitus mentis”: the search for new horizons, The Jurist 48 (1988), s. 429-447.

${ }^{57} \mathrm{~J}$ a n Paw e 1 I I, Constitutio Apostolica Sacrae disciplinae leges, 25 I 1983, AAS 75 (1983), s. 7-14.

${ }^{\text {sk }}$ S. Wronkowska, Z. Zi e mbiński, Zarys..., s. 122.

${ }^{59}$ K. Opalek, J. Wróblewski, Prawo. Metodologia, filozofia, teoria prawa, Warszawa 1991, s. 253-254.
} 
1. Jasność kwalifikacyjna, polegająca na braku wątpliwości co do kwalifikacji określonego stanu faktycznego w ogóle, a zachowania się w szczególności, z punktu widzenia obowiązującego prawa.

2. Jasność orientacji $w$ prawie, która wiąże się z pytaniami: kto, w jakich warunkach i w jaki sposób ma prawo lub obowiązek się zachować.

3. Jasność systematyzacji polega na braku wątpliwości co do zachodzenia określonych stosunków między regułami prawa lub między pojęciami prawnymi.

Wszystkie te rodzaje jasności prawa prawodawca powinien mieć na myśli pisząc ustawy. Zbyt duża liczba aktów prawnych czy też akty prawne zbyt obszerne i zawierające skomplikowane rozwiązania powodują, że prawo jest niejasne, a przez to traci swoją użyteczność. Nie wolno ustanawiać praw niepotrzebnych.

$\mathrm{Z}$ tego wyplywa szósta zasada: Pamiętaj o prawie zwyczajowym, czyli formie niepisanej prawa kościelnego. Choć jest ono marginalne w sensie liczebnym, to jednak nie ma potrzeby dublowania go poprzez akt prawa pisanego. Prawodawca powinien myśląc skromnie o swoich możliwościach prawotwórczych, o ile jest to zgodne $\mathrm{z}$ naczelnymi zasadami, których ma prawodawca bronić i jego wolą, dać pierwszeństwo rozwiązaniom spontanicznie praktykowanym przez wspólnotę.

Nadaj prawu odpowiednia range wynikajaca $z$ rodzaju dokumentu prawnego, to kolejny, siódmy już nakaz dla prawodawcy. Dokumenty wydawane przez władzę kościelną mają różną formę i znaczenie. Niektóre mogą zobowiązywać, inne zachęcać. Prawodawca ma obowiązek jasnego wyłożenia rangi swoich oświadczeń. R. Sobański pisze o wadze jasnego rozróżnienia dyspozycji proponujacych, zachęcających, pobudzajacych oraz dyspozycji normatywnych. Chodzi tu o (...) pewność prawna ${ }^{60}$.

Zadbaj o poprawny jezzk ustawy (o jej wlaściwe ttumaczenie); stosuj odpowiednie stowa i pamiętaj o kontekście użytych wyrazów. Ta ósma zasada jest lustrzanym odbiciem fundamentalnego dla poprawnego rozumienia kościelnych tekstów prawniczych kanonu kan. 17. Prawodawca przecież musi zdawać sobie sprawę, że jego tekst zostanie zinterpretowany według dyrektyw interpretacyjnych ${ }^{61}$.

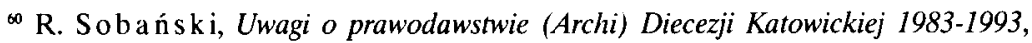
Prawo Kanoniczne 38 (1995) n. 1-2, s. 161.

${ }^{61}$ M. Zielińs ki, Wykladnia prawa.., s. 282. 
Tekst ustawy powinien więc być sformułowany jasno według zasad języka powszechnego, którego slownictwo jest zbiorem elementów danego języka etnicznego powszechnie dostępnych dla przeciętnego czlonka danej grupy etnicznej i w zwiazku z tym nadajacym sie do powszechnego użycia ${ }^{62}$. Prawodawca musi znać znaczenie użytego słowa: naturalne czyli etymologiczne, znaczenie słowa jakie jest w powszechnym użyciu, znaczenie jakie słowo ma w prawie ${ }^{63}$. Znaczenie pewnych wyrazów zostało ustawowo określone, a także należy mieć na względzie znaczenie, w jakim słowa używa tradycja kanoniczna. Wiele kanonicznych sformułowań ma standardowe, techniczne znaczenie, które jest znane kanonistom, lecz niekoniecznie innym ${ }^{\text {64 }}$.

Prawodawca musi pamiętać, że właściwe znaczenie słowa odczytuje się poprzez odniesienie do jego otoczenia w tekście i kontekście. Znaczenie słów zależy od sposobu i miejsca ich użycia, czyli z polożeniem słów w frazie, członie zdania, całym zdaniu czy paragrafie. Podobnie kontekst występowania słów takich jak, np.: artykuł, tytul, księga w kodeksie, zmienia znaczenie słów. Pewne modyfikacje mogą być też dokonane poprzez podkreślenia i interpunkcję ${ }^{65}$.

Następna dziewiąta zasada jest mocno powiązana $z$ poprzednią i brzmi: Badź świadom, że twoje slowa będa tlumaczone szeroko lub wasko. Ustawodawca musi dopuszczać niekiedy pewną elastyczność w ustalaniu treści i zakresu normy prawnej. Pewne zapisy prawne można tłumaczyć szerzej lub węziej bez naruszania ich oryginalnego znaczenia. Mówi o tym kan. 19, w którym zawarty jest obowiązek ścisłej interpretacji przepisów prawa. Obejmuje on trzy typy ustaw: ustawy stanowiące kary, ustawy zacieśniające swobodne wykonywanie praw, ustawy zawierające wyjątek od ustawy. To wyliczenie jest wyczerpujące ${ }^{6}$. Odnosi się ono tylko do ustaw. Nie obejmuje reskryptów, przywilejów i dyspens. Te grupy można więc tłumaczyć szeroko.

${ }^{62}$ M. Zi eliński, Interpretacja jako proces dekodowania tekstu prawnego, Poznań 1972, s. 7.

${ }^{63}$ Por. G. M ich i els, Normae generales iuris canonici, t. I, Lublin 1929, s. 404-405.

${ }^{4}$ Zwykle KPK nie definiuje swoich terminów, choć czasem jest inaczej, zob. np. kanony: $29,34,48,49,59$, itd.

${ }_{65}^{5}$ Por. J. A. Co ri d e n, Rules for Interpreters, [w:] The Art of Interpretation..., s. 20.

${ }^{\infty}$ W. Wó j c i k, Interpretacja ustaw wedlug nowego Kodeksu Prawa Kanonicznego, Prawo Kanoniczne 30 (1987), nr 3-4, s. 86. 
Niekiedy prawodawca celowo stosuje zwroty niedookreślone (ta cecha dotyczy ich znaczenia, czyli jest to właściwość o charakterze językowym) i nieostre (dotyczy zakresu zwrotów, czyli jest to właściwość o charakterze logicznym). Takie zabiegi mają na celu uelastycznienie tekstów, otwarcie ich na różnie przypadki prawne i danie większej swobody interpretacyjnej.

\section{Wnioski}

Działalność prawotwórcza w Kościele odbywa się w nim samym. Nie dochodzi ona z zewnątrz do Kościoła. Wyrasta z samego Kościoła i mieści się w jego przepowiadaniu ${ }^{67}$. Prawodawca ma wladzę, a jak pisze J. L. McKenzie tajemnica władzy kościelnej (czyli także i władzy ustawodawczej) polega na tym, że jest to taka wladza, której mocą jest moc miłości. Bo kiedy władza kościelna posługuje się jakąś inną mocą, to przestaje dawać dowody swojego chrześcijańskiego, kościelnego charakteru ${ }^{68}$. O procesie tworzenia prawa kościelnego L. Örsy mówi, że jest to mały udział w wielkiej milości Boga, która tworzy chrześcijańską wspólnotę ${ }^{69}$. Działając więc z miłością prawodawca może swoją prawotwórczą działalność zamienić w sztukę.

The church lawgiver and his art

This article originated in an effort to present a church lawgiver, his work, and some of the rules the lawgiver's work needs to follow to become an art. Rules for making the law should not stand in isolation from the rules that govern the interpretation of that law. In fact, rules for making the law should follow the rules of interpreting that very law.

The article consists of two parts. The first one presents the theory of lawgiving while the second offers the rules in question. These rules can be grouped into three categories.

Rules in terms of the person of the lawgiver:

1. Get to know yourself,

2. Be aware of your philosophical and theological horizon,

\footnotetext{
${ }^{67} \mathrm{R}$. Sobań ski, O procesach prawotwórczych $w$ Kościele, Śląskie Studia Historyczno-Teologiczne, XIX/XX (1986-87), s. 96.

${ }_{68}^{6}$ J. L. M c Ken zi e, Wladza w Kościele, Warszawa 1972, przeł. A. Korlińska, s. 227.

${ }^{69} \mathrm{~L}$. Ö r sy, The Creative Role of Constitutional Law in the Church, Studia Canonica 1 (1968), s. 324.
} 
3. Be prudent,

4. Acquire proper knowledge,

5. Thoroughly estimate the results of the chosen law solution and its alternatives.

Rules in terms of the community:

1. Take under consideration a community you serve,

2. Predict an acceptance of law,

3. Take care of acceptance and reception of law,

4. Listen to voices of community after the law comes into force.

Rules in terms of the text of the law:

1. Remember the role of the law in the Church,

2. Take care of the theological correctness of the law,

3. Make the law according to the thought of the Second Vatican Council,

4. Be familiar with the existing legislative system,

5. Do your best to formulate a clear law,

6. Take into account the common law,

7. Create a form of the law adequate to its importance,

8. Use proper language to write the law (take care of correct translation), use proper words, and remember about the context of used words,

9. Be aware that your words will be interpreted in wide or narrow way.

The lawgiving activity takes place within the church itself. It does not come to it from the outside. It flows naturally from the Church's mission to teach. The exercise of authority in the Church, and that includes the legislature, has its roots in love. When it fails to rely on love it is no longer a Church authority. The process of making church law can be called after L. Örsy: a small participation in the great love of God that presently and perpetually creates the Christian community ${ }^{71}$. We see that acting in accordance with love a church legislator is capable of turning his work into art.

${ }^{\pi}$ L. Örsy, The Creative Role of Constitutional Law in the Church, Studia Canonica 1 (1968), s. 324. 